\title{
IMPLEMENTASI PROGRAM IMTAQ DALAM MENUNJANG PEMBELAJARAN RUMPUN PENDIDIKAN AGAMA ISLAM (PAI) DI MADRASAH SWASTA LOMBOK BARAT (Studi Kasus di MI Nurul Karim NW Kebon Ayu Gerung)
}

\section{Abdul Fattah*}

\begin{abstract}
Abstrak: pelaksanaan program imtaq di MI NW Nurul Karim Desa Kebon Ayu Kecamatan Gerung Kabupaten Lombok Barat tidak hanya dilaksanakan pada jam formal pada hari Jum'at pagi misalnya, namun juga diperluas waktunya pada waktu lain di luar jam Sekolah/Madrasah/ madrasah formal, seperti melaksanakan "Acara Hiziban NW" rutin setiap minggu. Artikel ini bertujuan untuk mengeksplorasi implementasi program imtaq di MI NW Nurul Karim. Temuan artikel ini menunjukkan bahwa dengan adanya program imtaq yang dilaksanakan secara rutin tersebut, telah membawa hasil dengan terjadinya perubahan yang signifikan pada anak didik di MI Nurul Karim NW Kebon Ayu Gerung Kabupaten Lombok Barat. Perubahan-perubahan tersebut mencakup aspek kognitif, afektif, dan psikomotorik yang ditandai dengan tertanamnya kebiasaan-kebiasaan berbuat baik anak didik di lingkungan Madrasah maupun di luar lingkungan Madrasah.
\end{abstract}

Kata Kunci: Program Imtaq, MI Nurul Karim NW Gerung, Program Imtaq Harian, Program Imtaq Mingguan, Program Imtaq Bulanan, dan Program Imtaq Setiap Tahun.

\section{Pendahuluan}

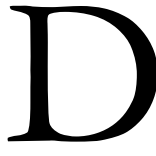

alam masyarakat yang dinamis, pendidikan memegang peranan yang sangat menentukan terhadap eksistensi dan perkembangan masyarakat, hal ini karena pendidikan merupakan proses usaha melestarikan, mengalihkan serta mentranspormasikan nilai-nilai kebudayaan dalam aspek dan

* Penulis adalah Dosen Tetap Jurusan PAI FTK UIN Mataram, e-mail: fath_smart@yahoo.com 
jenisnya kepada generasi penerus. Demikian pula dengan peranan Pendidikan Agama Islam, keberadaannya merupakan salah satu bentuk manifestasi dari cita-cita hidip Islam yang bisa melestarikan, mengalihkan dan menginternalisasikan (menanamkan) dan mentransformasikan nilai-nilai Islam kepada generasi penerusnya (Arifin 2008, 8).

Pendididkan agama dimaksudkan untuk membangun aspek keimanan dan ketakwaan sebagaimana yang diamanatkan dalam undang-undang No 2, pendidikan agama ini didefinisikan menjadi usaha-usaha secara sistematis dan pragmatis dalam membantu anak didik agar mereka hidup sesuai dengan ajaran Islam.

Untuk mengantisipasi hal-hal yang merusak generasi muda itu, maka kegiatan keagamaan tidaklah cukup dengan melalui kegiatan belajar di kelas dalam waktu 2 jam pelajaran seminggu, akan tetapi, kegiatan keagamaan itu juga seharusnya secara efektif dilaksanakan diluar jam pelajaran secara terkoordinir maka dengan kondisi yang demikian keberadaan program imtaq adalah merupakan salah satu alternatif yang harus dilaksanakan di Sekolah/Madrasah/ madrasah.

Adapun materi untuk pesarta program imtaq ini merupakan rangkaian materi yang meliputi, keimanan, ibadah, al-Qur'an dan akhlak, sedangkan kemampuan dasar yang diharapkan adalah agar para anak didik memiliki pengetahuan yang cukup dalam memahami dan menghayati dan menyimpulkan kandungan ayat alQur'an, memiliki ahlakul karimah kepada Allah SWT, ibu dan bapak, orang lain dan lingkungan hidup lainnya, mengetahui ketentuan agama Islam, serta memiliki kepekaan dan kepedulian sosial.

Pelaksanaan program imtaq tersebut memberi harapan baru kepada masyarakat terutama para pengelola pendidikan dengan diadakannya kegiatan-kegiatan yang mendorong (menumbuh kembangkan) keimanan dan ketakwaan serta mendidik guna mencapai tujuan tujuan Pendidikan Agama Islam, sebagaimana yang diharapkan. Selama pengamatan peneliti masih banyak hal yang harus dibenahi terutama dari segi pembinaan, perencanaan program, dan lain sebagainya (Observasi, tanggal 12 Maret 2017). 
Permasalahan yang dihadapi dalam pelaksanaan program imtaq di MI NW Nurul Karim Desa Kebon Ayu Kecamatan Gerung Kabupaten Lombok Barat di antaranya adalah: (1). Tidak maksimalnya perhatian khusus siswa dalam mengikuti pelaksanaan program imtaq, (2). Siswa tidak terfokus mengikuti kegiatan imtaq, (3). Masih ada siswa yang main-main, ngobrol dan lain sebagainya. Di satu sisi bahwa program imtaq di MI ini tidak hanya dilaksanakan pada jam formal pada hari Jum'at pagi misalnya, namun juga diperluas waktunya pada waktu lain di luar jam Sekolah/Madrasah/ madrasah formal, seperti melaksanakan "Acara Hiziban NW" rutin setiap minggu. Atas dasar itu, peneliti tertarik melakukan penelitian di madrasah ini sebagai representasi madrasah swasta di Kabupaten Lombok Barat. Pada sisi yang lain, peneliti ingin mengetahui lebih lanjut sejauh mana penghayatan siswa terhadap materi dari program imtaq terkait dengan materi rumpun Pendidikan Agama Islam (mapel Aqidah Akhlaq, Fiqih, Qur'an Hadits, SKI dan Bahasa Arab) yang telah diperoleh di madrasah. Di samping itu juga program imtaq juga merupakan program yang wajib diikuti oleh semua siswa- siswi dalam rangka mengamalkan dan menginternalisasi ajaran agama Islam yang diperoleh di dalam kelas.

Pelaksanaan program imtaq tersebut tentunya tidak terlepas dari permasalahan yang dihadapi, baik permasalahan tersebut timbul dari diri manusia (internal) maupun dari luar diri manusia (eksternal). Kendati demikian muncul pertanyaan, apakah pelaksanaan imtaq tersebut sudah betul-betul dilaksanakan sesuai dengan yang diprogramkan atau hanya merupakan kegiatan seremonial belaka.

\section{Sejarah berdirinya MI Nurul Karim NW Kebon Ayu Gerung}

Madrasah Ibtidaiyah Nurul Karim NW merupakan salah satu lembaga pendidikan Islam tingkat dasar pertama di bawah naungan Kementerian Agama (khususnya Kabupaten Lombok Barat). Madrasah tersebut berada di Desa Kebon Ayu Kecamatan Gerung Kabupaten Lombok Barat. Madrasah Ibtidaiyah Nurul Karim 
sebagai sarana dalam pendidikan bertujuan untuk mencetak siswasiswi yang berwawasan luas dan beriman serta betaqwa kepada Tuhan Yang Maha Esa.

Kalau ditelusuri secara singkat Madrasah Ibtidaiyah Nurul Karim NW didirikan pada tahun 1987. Pada saat itu lembaga pendidikan yang bernuansa religius yang setingkat dengan SD di Kabupaten Lombok Barat masih minim khususnya di Kecamatan Gerung. Maka mulai tahun 1987 munculah ide-ide untuk mendirikan Madrasah Ibtida'iyah, sehingga pada tahun 1987/1988 ide-ide itu bisa terealisasi dan pada tahun itu juga diresmikan sebagai lahirnya/berdirinya lembaga pendidikan Madrasah Ibtidaiyah Nurul Karim.

Adapun hal-hal khusus yang melatarbelakangi berdirinya Madrasah Ibtidaiyah Nurul Karim NW Kebon Ayu adalah:

a) Adanya animo-animo dari masyarakat.

b) Terbatasnya lembaga pendidikan Agama di Desa Kebon Ayu Kecamatan Gerung, Kabupaten Lombok Barat.

c) Kebutuhan siswa di sekitar daerah Kebon Ayu yang sangat mendesak. (Mukrim, S.Pd.I, Kepala Madrasah, wawancara, tanggal 28 Agustus 2017)

Sejak awal berdirinya hingga saat ini yang terhitung cukup lama MI Nurul Karim NW telah mengalami perkembangan yang cukup pesat baik dalam bidang agama maupun dalam bidang umum, hal ini dapat terlihat dari banyaknya siswa-siswi yang berprestasi dalam lomba-loba keagamaan maupun lomba-lomba yang bersifat umum, seperti Tahfizul Qur'an, cerdas cermat, pidato bahasa Inggris dan bahasa Arab, dan sebagainya (Kamahar, S.Pd.I, Wakil Kepala Madrasah, wawancara, tanggal 01 September 2017).

\section{Bentuk-bentuk Pelaksanaan Program Imtaq di MI Nurul Karim NW Kebon Ayu Gerung}

Pelaksanaan program imtaq (iman taqwa) yang ada di MI Nurul Karim NW Kebon Ayu Gerung Lombok Barat terlaksana sesuai dengan prosedur yang ada. Semua warga Sekolah/Madrasah MI Nurul Karim NW Kebon Ayu Gerung wajib mengikuti semua 
program imtaq tersebut, baik itu dari pihak kepala Sekolah/Madrasah, guru-guru, pegawai dan tidak terkecuali siswasiswi yang menjadi sasaran dari program imtaq tersebut.

Gambaran tentang pelaksanaan program imtaq di MI Nurul Karim NW Kebon Ayu Gerung datanya peneliti dapatkan melalui interview atau wawancara dengan kepala Sekolah/Madrasah MI Nurul Karim NW Kebon Ayu Gerung, guru-guru Mapel Qur'an Hadits dan para pembina imtaq yang ada di MI Nurul Karim NW Kebon Ayu Gerung dan tidak terkecuali siswa, di samping itu juga peneliti menggunakan metode observasi dan dokumentasi dan melibatkan diri secara langsung saat program imtaq berlangsung.

Kepala Sekolah/Madrasah MI Nurul Karim NW Kebon Ayu Gerung (Mukrim) mengemukakan bahwa program imtaq merupakan salah satu program yang telah cukup lama dilaksanakan di MI Nurul Karim NW Kebon Ayu Gerung, program imtaq ini sasarannya kepada semua siswa-siswi MI Nurul Karim NW Kebon Ayu Gerung tanpa terkecuali dan siswa-siswi diharapkan mengikuti semua kegiatan program imtaq tersebut (Observasi dan Wawancara, tanggal 18 Mei 2017).

Menurut H. Abdillah Karim (pembina imtaq), program imtaq ini harus diikuti oleh semua pihak yang ada di dalam lingkungan Sekolah/Madrasah MI Nurul Karim NW Kebon Ayu Gerung tidak terkecuali seluruh siswa dan siswi yang harus mengikutinya, karena program imtaq yang dilaksanakan ini tidak terlepas dari tujuan pada guru yaitu untuk menggembleng para siswa-siswi dalam menanamkan keimanan dan ketaqwaan sebagai bekal agar nantinya siswa dan siswi dapat membedakan mana yang baik dan mana yang buruk yang akan mereka temui nantinya dalam kehidupan seharihari (Wawancara, tanggal 18 Mei 2017).

Sementara menurut Kamahar selaku guru Al-Qur'an Hadits menjelaskan di samping program imtaq ini penting diikuti oleh siswa dan siswi dalam menanamkan keimanan dan ketaqwaan yang akan menjadi bekal kehidupan dari siswa-siswi, program imtaq ini juga penting sekali sebagai tambahan dari rumpun pelajaran Pendidikan Agama Islam (seperti Qur'an Hadits, Aqidah Akhlak, 
Fiqih, SKI dan Bahasa Arab) yang diajarkan di kelas. Jadi siswasiswi tidak hanya mendapatkan ilmu agama hanya di dalam kelas saja akan tetapi siswa-siswi juga mendapatkannya dari program imtaq ini karena materi-materi program imtaq ini juga diambil dari materi-materi rumpun pelajaran Pendidikan Agama Islam (PAI) yang mereka pelajari di dalam kelas, maka dari itu program ini sangat membantu dalam pembinaan iman dan takwa serta pemahaman dan penghayatan terhadap nilai-nilai ajaran agama (Wawancara, tanggal 18 Mei 2017).

Dari paparan diatas terlihat jelas bahwa pelaksanaaan program imtaq di MI Nurul Karim NW Kebon Ayu Gerung sangat membantu dalam menanamkan keimanan dan ketaqwaan sisw-siswi MI Nurul Karim NW Kebon Ayu Gerung dalam kaitannya dengan bagaimana siswa-siswi memaknai dan menghayati ajaran agama Islam dan pelaksanaannya sesuai dengan prosedur yang ada di MI Nurul Karim NW Kebon Ayu Gerung dan wajib diikuti oleh semua warga yang ada dilingkungan Sekolah/Madrasah.

Adapun bentuk-bentuk dari kegiatan program imtaq yang dilaksanakan di MI Nurul Karim NW Kebon Ayu Gerung dibagi menjadi tiga tahap/bagian yaitu: (1) kegiatan harian, (2) kegiatan mingguan dan (3) kegiatan tahunan. Berikut perincian dari masingmasing kegiatan dari program imtaq yang ada di MI Nurul Karim NW Kebon Ayu Gerung.

\section{Kegiatan Harian}

\section{Sholat Dhuba}

Berdasarkan pengamatan peneliti di lapangan, setiap harinya siswa-siswi mengadakan sholat dhuha di musolla yang ada di lingkungan MI Nurul Karim NW Kebon Ayu Gerung yang mempunyai alokasi waktu 15 menit, dari pukul 07.30 sampai dengan 07.45. kegiatan ini merupakan wujud dan inplementasi dari salah satu materi program imtaq yaitu materi ibadah. Dengan kegiatan sholat duha ini diharapkan agar siswa-siswi termotivasi dan terbiasa untuk melaksanakan ibadah sholat sunnat lainnya. Di dalam mengerjakan shalat dhuha para siswa-siswi terlihat tertib dan 
tetap menjaga formasi shaf yang telah dibentuk sehingga tercipta suasana yang tenang dan Islami. Namun tidak jarang siswa-siswi yang tidak ikut melaksanakan shalat dhuha tersebut dikarenakan mereka tidak memahami shalat yang diajarkan guru, mereka terlihat tidak membawa perlengkapan solat dan lain sebagainya (Observasi, tanggal 22 Mei 2017).

\section{Berpakaian Muslim}

Menutup aurat merupakan kewajiban setiap muslimlaki-laki dan perempuan, menutup aurat merupakan salah satu ajaran Islam yang sangat penting untuk diterapkan didalam pelaksanaan program imtaq, karena dengan menerapkan kegiatan ini dapat melatih dan membiasakan anak didik dalam berpakaian yang sesuai dengan ajaran Islam dan untuk menyadarkan anak didik akan arti pentingnya menutup aurat, oleh karena itu kegiatan ini sangat tepat untuk diterapkan.

Dalam hal ini kepala Sekolah/Madrasah (Mukrim) mengeluarkan kebijakan demi untuk mensukseskan semua program imtaq yaitu memakai jilbab rapi bagi siswi MI Nurul Karim NW Kebon Ayu Gerung baik yang dilakukan setiap hari maupun sekali dalam seminggu, maka berdasarkan pengamatan dan hasil wawancara dengan kepala Madrasah, peneliti melihat bahwa hanya sebagian saja siswi MI Nurul Karim NW Kebon Ayu Gerung yang memakai jilbab kurang rapi. Khusus untuk Jum'at pagi semua siswa-siswi berbusana muslim dengan rapi untuk melaksanakan imtaq pagi Jum'at. Siswa-siswi ini selalu berpakaian rapi dan tidak menyalahi aturan-aturan Sekolah/Madrasah seperti tidak memakai pakaian yang dicoret-coret dan tidak memakai celana yang robek (Wawancara dan Observasi, tanggal 21 Mei 2017).

Kegiatan Membaca Al-Qur'an

Tadarus/membaca Al-Qur'an merupakan rangkaian kegiatan membawa Al-Qur'an, kegiatan ini dilaksanakan setiap hari kecuali hari Jum'at selama 20 menit atau dari pukul 07.10 sampai dengan 
07-30 sebelum memulai pelajaran, selama kegiatan ini berlangsung semua siswa-siswi diharuskan membaca Al-Quran.

Menurut Kamahar (guru mapel Qur'an Hadits) mengemukakan bahwa tujuan dari pelaksanaan tadarus (membaca) Al-Qur'an setiap harinya adalah untuk memotivasi siswa-siswi agar gemar membaca Al-Quran, serta agar siswa-siswi mampu mengungkapkan kandungan-kandungan ayat-ayat Al-Qur'an. Kemudian ia juga mengungkapkan kembali semua bentuk-bentuk kegiatan program imtaq tersebut, baik yang dilaksanakan setiap hari maupun satu kali dalam seminggu yang bertujuan untuk memperdalam, memantapkan, dan meningkatkan penghayatan ajaran agama Islam anak didik di bidang keimanan, ibadah, al-Qur'an dan akhlak dan selanjutnya diharapkan berpengaruh pada peningkatan iman dan taqwa dari peserta didik tersebut (Wawancara, tanggal 21 Mei 2017).

\section{Kegiatan Mingguan}

Sesuai dengan hasil pengamatan di lapangan, kegiatan program imtaq yang dilaksanakan sekali dalam seminggu yang diadakan setiap hari jumat selama 50 menit, mulai pukul 07.10 sampai dengan 08.00 pagi, kegiatan ini tidak hanya diisi oleh guru saja tetapi juga diisi oleh siawa-siswi itu sendiri yang berasal dari masing-masing kelas, mulai dari kelas I sampai dengan kelas III secara bergantian setiap Jumat pagi, dengan perincian waktu kurang lebih 20 menit untuk siswa, 15 menit untuk guru dan dan 15 menit untuk kegiatan Yasinan (Observasi, tanggal 25 Mei 2017).

Adapun kegiatan program imtaq setiap minggunya yaitu pada hari Jum'at pagi adalah sebagai berikut:

\section{Membaca Surat Yasin Bersama}

Kegiatan membaca surat Yasin bersama ini dilakukan sebelum kultum (kuliyah tujuh menit), semua siswa-siswi wajib mengikuti kegiatan membaca surat Yasin bersama yang dipimpin oleh guru Pendidikan Agama Islam, pembina imtaq, adapun disini siswa-siswi bergiliran memimpin membaca surat yasin ini. Menurut $H$. Abdillah Karim sebagai pembina imtaq di MI Nurul Karim NW 
Kebon Ayu Gerung ini, dengan siswa disuruh memimpin membaca surat yasin setiap minggunya agar nantinya siswa-siswi terbiasa melakukannya di mana saja mereka berada, dan agar para siswa dan siswi dapat membaca al-Qur'an serta mengerti makna yang terkandung dalam surat Yasin tersbut karena surat Yasin itu sangat penting untuk diamalkan (Wawancara, tanggal 25 Mei 2017).

\section{Kultum (Kuliab Tujub Menit)}

Sebagai kegiatan akhir atau penutup dari pelaksanaan program imtaq setiap jumat pagi ialah: kultum yaitu kuliyah tujuh menit, kegiatan ini khusus diisi oleh guru agama selama 15 menit, namun sebelum kultum disampaikan oleh guru agama atau pembina imtaq terlebih dahulu siswa-siswi dari masing-masing kelas secara bergiliran setiap minggunya menyampaikan pidato secara singkat sebagai latihan untuk para siswa dan siswi agar nantinya mereka terbiasa berbicara di hadapan umum. Kemudian setelah siswa selesai baru lah guru menyampaikan kultum tersebut yang isinya selalu terkait dengan materi-materi Pendidikan Agama Islam seperti masalah keimanan, iman, ihsan, pengaruh keimanan yang bersemayam di dalam diri siswa yang terkait dengan bagaimana penghayatan siswa terhadap materi Pendidikan Agama Islam yang diajarkan di dalam kelas setiap harinya, serta terkait dengan masalah akhlak seperti macam-macam akhlak terpuji, bentuk akhlak kepada Allah sikap terhadap Al-Qur'an dan kesadaran beribadah (Observasi, tanggal 18 Mei 2017).

\section{Pengumpulan Amal Setiap Selesai Program Imtaq}

Sebagai kegiatan setelah selesai membaca surat yasin dan kultum (kuliyah 7 menit) dari masing-masing kelas yang dikoordinir oleh masing-masing ketua kelas melakukan kegiatan pengumpulan amal. Bagi siswa yang mau beramal menyerahkan kepada ketua kelas dan dalam sumbangan ini siswa tidak dipaksa harus mengeluarkan beberapa saja seikhlasnya, amal yang sudah terkumpul lalu disertakan langsung kepada wali kelas masing- 
masing dan dikelola sebaik mungkin sebagai dana pembangunan dan lain sebagainya seperti membeli hewan kurban tiap tahunnya.

Menurut Kamahar (guru bidang study PAI) mengatakan bahwa dana amal yang sudah terkumpul tersebut digunakan untuk kepentingan Sekolah/Madrasah, biasa digunakan untuk memperbaiki kerusakan yang ada diSekolah/Madrasah, pembelian hewan kurnban setiap tahunnya dan sebagiannya juga sering disumbangkan untuk dana pembangunan masjid, tujuan dari kegiatan ini adalah agar nantinya siswa-siswi terbiasa menyisakan uang mereka untuk bisa disumbangkan demi kepentingan umum dan agar mereka terbiasa memberikan sebagian uang mereka untuk orang lain yang membutuhkan (Wawancara, tanggal 25 Mei 2017).

\section{Kegiatan Bulanan}

Kegiatan bulanan ini biasanya dilakukan setiap bulannya, biasanya kegiatan setelah semester dan kegiatan pada bulan Ramadhan.

\section{Kegiatan Semester}

Menurut Kamahar selaku guru Mapel Qur'an Hadits kegiatan semester ini dilakukan pada saat setelah selesai semester sebelum siswa-siswi diberikan hasil ujian semester biasanya dirangkaikan dengan kegiatan class meeting. Diantara kegiatan yang dijalankan yaitu:

a. Lomba menghapal ayat-ayat Al-Qur'an,

b. Lomba pidato,

c. Cerdas cermat,

d. Lomba puisi Islami,

e. Seleksi membaca Al-Quran antar kelas. (Wawancara, tanggal 28 Mei 2017)

\section{Kegiatan Bulan Ramadhan}

Kegiatan ini merupakan salah satu cara agar kegiatan imtaq ini berjalan sesuai dengan apa yang diharapkan. Kegiatan ini juga harus diikuti oleh semua siswa-siswi MI Nurul Karim NW Kebon Ayu 
Gerung sebagai kegiatan mereka selama bulan suci Ramadhan. Menurut Mukrim (Madrasah MI Nurul Karim NW Kebon Ayu Gerung) bentuk-bentuk kegiatan bulan suci Ramadhan meliputi:

a. Berbuka puasa bersama yang tujuannya adalah mempererat tali silaturrahmi antar semua warga Sekolah/Madrasah.

b. Sholat tarawih bersama yang diikuti oleh semua siswa-siswi.

c. Tadarus bersama, biasa dilaksanakan hanya 4 kali selama kegiatan ini.

d. Pengumpulan zakat fitrah, siswa dan siswi diharuskan mengumpulkan zakat fitrah di Madrasah dan nantinya Madrasah yang akan memberikan kepada orang yang berhak menerimanya.

e. Kegiatan Nuzulul Qur'an, perayaan Nuzulul Qur'an ini dilaksanakan bersamaan dengan kegiatan-kegiatan program imtaq yang lainnya yang diadakan di bulan Ramadhan. (Wawancara, tanggal 25 Mei 2017)

\section{Kegiatan Tahunan}

Menurut Kamahar (guru Mapel Qur'an Hadits) kegiatan program imtaq yang diadakan setiap tahunnya terbilang tidak pernah tidak dilaksanakan, adapun kegiatan setiap tahunnya meliputi:

a. Pemotongan hewan Qurban, pemotongan hewan Qurban ini biasa selalu dilaksanakan setiap tahunnya, biasanya Sekolah/Madrasah membeli 2 ekor sapi untuk di Qurban bersama.

b. Perayaan Isra' Mi'raj nabi Muhammad SAW.

Dalam kegiatan ini Madrasah melakukan kegiatan pengajian yang rutin dilakukan setiap kali perayaan hari besar Islam di MI Nurul Karim NW Kebon Ayu Gerung yang diikuti oleh semua warga yang ada di Madrasah MI Nurul Karim NW Kebon Ayu Gerung.

c. Perayaan maulid Nabi Muhammad SAW.

Tidak jauh berbeda dengan perayaan maulid Nabi Muhammad SAW, dalam kegiatan isra' mi'raj juga diadakan 
pengajian sebagai tanda mengingat sejarah Nabi Muhammad SAW untuk umat manusia.

d. Halal bi Halal setiap selesai perayaan Idul Fitri dan Idul Adha.

Halal bi halal ini dilaksanakan tujuannya untuk mempererat tali persaudaraa antar semua warga Sekolah/Madrasah baik itu dari pihak kepala Sekolah/Madrasah, guru-guru, siswa maupun dari pihak pegawai-pegawai lainnya. (Wawancara, tanggal 28 Mei 2017)

\section{Faktor Pendukung Program Imtaq Di MI Nurul Karim NW Kebon Ayu Gerung}

Di dalam pelaksanaan program imtaq ini, menurut Dedi Satriawan (guru Mapel Bahasa Arab) ada banyak faktor yang mendukung di antaranya:

a. Faktor Anak Didik

Faktor anak didik merupakan salah satu faktor yang paling penting karena tanpa adanya anak didik tersebut maka dalam suatu kegiatan pendidikan termasuk kegiatan program imtaq tidak akan berlangsung, oleh karena itu, proses Pendidikan Agama Islam termasuk program imtaq tidak terlepas dari peserta didik karena peserta didik merupakan sasaran utama dari proses program imtaq dan program pendidikan lainnya, karena bagaimanapun anak didik adalah generasi penerus harapan masyarakat dan bangsa tentunya tidak terlepas dari pembinaan dan bimbingan.

Menurut Hasanuddin (guru mapel SKI) mengemukakan bahwa peserta didik merupakan sasaran utama dalam suatu kegiatan yang dilakukan di Sekolah/Madrasah, baik itu kegiatan yang bersifat umum maupun kegiatan yang bentuknya keagamaan, menurutnya peserta didik dituntut untuk melasanakan semua kegiatan yang sudah diprogramkan agar nantinya semua kegiatan tersebut bisa berjalan dengan lancar sesuai dengan tujuan yang ingin dicapai. Adapun tujuan yang ingin dicapai antara lain adalah: 
a) Untuk memperdalam wawasan peserta didik tentang makna-makna yang terkandung dalam ibadah-ibadah yang diperintahkan agama, sehingga mampu mengimplementasikan nilai-nilai ajaran agama dalamnya dalam kehidupan sehari-hari.

b) Menumbuhkan sikap mental yang jujur, ikhlas (sadar), tegas, dan berani dalam menjalankan tanggung jawabnya.

c) Antusias siswa dalam mengikuti kegiatan program imtaq yang dilaksanakan diSekolah/Madrasah, baik itu kegiatan harian, mingguan, bulanan/ smester dan kegiatan tahunan.

d) Melatih keterampilan dan kesdisiplinan peserta didik dalam menjalankan ritual keagamaan. (Wawancara, tanggal 28 Mei 2017)

b. Faktor Pendidik/Pembimbing

Pemdidik/ pembimbing adalah salah satu paktor yang sangat penting, karena pendidik itulah yang akan bertanggung jawab dalam pembentukan anak didik.

Menurut Mukrim (kepala Sekolah/Madrasah MI Nurul Karim NW Kebon Ayu Gerung) seluruh kegiatan dalam pelaksanaan program imtaq secara keseluruhan terkordinir dan dipantau langsung oleh semua guru, guru memberikan bimbingan dan pengajaran tentang apa yang akan dilaksanakan dalam kegiatan program imtaq, apapun bentuk kegiatan yang dilaksanakan di MI Nurul Karim NW Kebon Ayu Gerung semua guru harus ikut serta terutama guru pembina dari program imtaq (Wawancara, tanggal 21 Mei 2017).

\section{Faktor Penghambat Terlaksananya Program Imtaq Di MI Nurul Karim NW Kebon Ayu Gerung}

Di antara faktor-faktor yang menghambat pelaksanaan program imtaq di MI Nurul Karim NW Kebon Ayu Gerung menurut pembina imtaq (H. Abdillah Karim) adalah sebagai berikut: 
a. Dilihat dari sarana dan prasarana yang ada di MI Nurul Karim NW Kebon Ayu Gerung terbilang masih kurang memadai dalam menunjang program imtaq, dalam observasi yang dilakukan oleh peneliti, peneliti menemukan kurang memadainya tempat pelaksanaan program imtaq atau musholla yang ada di lingkungan Sekolah/Madrasah terbilang masih kecil untuk digunakan sebagai tempat pelaksanaan program imtaq, siswa masih duduk di depan kelas waktu pelaksanaan program imtaq khususnya hari Jum'at, karpet yang siswa gunakan masih kurang sehingga siswa duduk menggunakan sepatu mereka untuk duduk (Observasi, tanggal 28 Mei 2017).

b. Daya serap siswa terhadap materi program imtaq, dalam masalah ini siswa masih ada yang tidak terlalu memperhatikan kegiatan dari program imtaq sehingga materi-materi program imtaq tidak terserap secara keseluruhan.

c. Lingkungan masyarakat, di mana lingkungan bergaul siswa merupakan faktor yang sangat berpengaruh terhadap diri siswa, selain itu, lanjutnya, pengruh orang tua siswa itu sendiri dalam mendidik, mengarahkan anaknya. (Wawancara, tanggal 28 Mei 2017)

Menurut Apna (guru mapel Akidah Akhlaq) mengatakan bahwa: lingkungan mempunyai peranan yang sangat penting terhadap berhasil atau tidakanya suatu kegiatan yang dijalankan, karena perkembanga jiwa anak tersebut sangat dipengaruhi oleh keadaan lingkungannya, lingkungan dapat memberikan pengaruh yang positif maupun pengaruh yang negatif terhadap pertumbuhan jiwa seorang anak dalam akhlak lebih-lebih agamanya (Wawancara, tanggal 28 Mei 2017).

MI Nurul Karim NW Kebon Ayu bersebelahan dengan pasar yang ada di desa Kebon Ayu, jadi setiap harinya di lingkungan ini ramai oleh kegiatan pasar, maka dari itu kegiatan program imtaq khususnya hari Jum'at kurang terlaksana dengan baik karena keramaian yang ditimbulkan di luar lingkungan Sekolah/Madrasah, 
dan siswa siswi sendiri tidak akan terfokus jika alat yang digunakan kurang keras dan kurang jelas. Ini merupakan salah satu faktor penghambat dari pelaksanaan program imtaq di lingkungan MI Nurul Karim NW Kebon Ayu Gerung Lombok Barat (Abdul Karim, wawancara, tanggal 18 Mei 2017).

Dari berbagai paparan yang disampaikan oleh pembina imtaq di atas seharusnya hambatan-hambatan yang ada dalam pelaksanaan program imtaq tersebut harusnya bisa diselesaikan bersama agar kegiatan-kegiatan dari program imtaq tidak terhambat dan berjalan sesuai yang diharapkan bersama.

\section{Urgensi Program Imtaq dalam Menunjang Pembelajaran Rumpun Pendidikan Agama Islam di MI Nurul Karim NW}

Dari hasil wawancara dengan siswa-siswi (Gita Giovani dan teman-teman) menyatakan: Dengan diterapkannya program imtaq dan tujuan program imtaq di MI Nurul Karim NW Kebon Ayu Gerung, Lombok Barat, maka kami tidak terlalu kesulitan di dalam memahami materi-materi dalam rumpun Pendidikan Agama Islam yang diberikan oleh guru Fiqih, Akidah Akhlak, Qur'an Hadits, SKI, dan Bahasa Arab di dalam kelas, karena semua meteri-materi yang diberikan kadang-kadang sudah dibahas pada waktu pelaksanaan program imtaq (Wawancara, tanggal 31 Mei 2017).

Hal ini juga dibenarkan oleh kepala Sekolah/Madrasah (Mukrim) dan guru-guru dan pembina program imtaq di MI Nurul Karim NW Kebon Ayu Gerung. Guru-guru tersebut mengatakan bahwa memang dengan adanya program imtaq ini para siswa-siswi cukup mudah memahami semua meteri-materi mata pelajaran dalam rumpun Pendidikan Agama Islam yang diberikan (seperti Fiqih, Akidah Akhlak, Qur'an Hadits, SKI, dan Bahasa Arab) (Wawancara, tanggal 28 Mei 2017).

Dengan intensifnya pelaksanaan program imtaq ini, maka menurut pengamatan peneliti bahwa program imtaq telah mampu membawa perubahan yang signifikan didalam pembentukan prilaku yang positif bagi anak. Hal ini dapat dibuktikan dengan cara bergaul siswa-siswi yang sangat baik dan saling menghormati antar guru 
dan siswa. Jadi dengan keberadaan program imtaq ini mampu membantu siswa dan siswi dalam memahami dan menghayati ajaran Islam atau materi-materi Pendidikan Agama Islam yang sudah diajarkan didalam kelas oleh guru-guru Pendidikan Agama Islam serta mampu mengamalkan apa yang sudah didapatkan dalam pelajaran ke dalam kehidupan sehari-hari dari masing-masing peserta didik (Wawancara, tanggal 28 Mei 2017).

Sedangkan menurut Kamahar dan $\mathrm{H}$ Mutaalli mengatakan bahwa dampak yang paling menguntungkan dari pelaksanaan program imtaq ini antara lain: semakin kecilnya kualitas pelanggaran terhadap tata tertib Sekolah/Madrasah. Dan dari data prestasi siswa dalam pelajaran bidang studi Pendidikan Agama Islam selalu saja meningkat sesuai dengan harapan bersama dengan adanya program imtaq yang dijalankan oleh siswa-siswi di MI Nurul Karim NW Kebon Ayu Gerung ini (Wawancara, tanggal 31 Mei 2017).

Kenyataan tersebut sejalan dengan hasil observasi di lapangan, peneliti melihat bahwa jumlah siswa-siswi yang melanggar tata tertib dengan skor yang sedikit seperti ditemukannya siswa-siswi yang terlambat datang ke Sekolah/Madrasah dan tidak memasukkan baju (Observasi, tanggal 31 Mei 2017).

Selanjutnya dari hasil observasi peneliti di lapangan pada saat siswa-siswi berada di luar lingkungan Sekolah/Madrasah (ketika keluar main dan pulang Sekolah/Madrasah), mereka tidak pernah berbuat keributan atau kegaduhan dan sampai mengganggu penduduk di sekitar lingkungan Sekolah/Madrasah.

Keberadaan dari program imtaq ini sangatlah penting bagi para siswa-siswi karena program imtaq ini sangat membantu siswa-siswi dalam memahami, menghayati tentang apa yang sudah didapatkan di dalam kelas terkait dengan materi-materi dalam rumpun Pendidikan Agama Islam (Fiqih, Akidah Akhlak, Qur'an Hadits, SKI, dan Bahasa Arab), mereka akan lebih mengerti dan memahami bagaimana cara bersikap dan bertingkah laku yang baik sesuai dengan apa yang diajarkan oleh Islam. Hal yang terpenting yang didapatkan dari pelaksanaan program imtaq ini adalah bahwa 
siswa-siswi dapat memahami pelajaran atau materi-materi Pendidikan Agama Islam yang sudah didapatkan di dalam kelas dan mampu dilaksanakan apa yang sudah didapatkan didalam kehidupan sehari-hari artinya, program imtaq ini adalah program yang memperkuat apa yang telah siswa-siswi dapatkan di dalam materi-materi dalam rumpun PAI dan dapat diaplikasikan dalam kehidupan sehari-hari.

Sedangkan menurut kepala Sekolah/Madrasah (Mukrim) mengemukakan bahwa dengan keberadaan kegiatan program imtaq yang dilaksanakan di MI Nurul Karim NW Kebon Ayu Gerung Lombok Barat ini, baik kegiatan yang dilaksanakan setiap hari, setiap minggu maupun setiap bulan dan tahunnya sangat membawa pengaruh yang sangat baik dalam perkembangan peserta didik MI Nurul Karim NW Kebon Ayu Gerung. Jadi di sini semua kegiatan yang ada tidak kalah dengan Sekolah/Madrasah lain meskipun status MI Nurul Karim NW Kebon Ayu Gerung ini merupakan madrasah swasta namun kegiatan keagamaan yang dilaksanakan tidak kalah dengan Madrasah negeri yang nota bene memiliki fasilitas yang lengkap (Wawancara, tanggal 26 Mei 2017).

Dari paparan penjelasan diatas dapat disimpulkan bahwa keberadaan dari program imtaq di MI Nurul Karim NW Kebon Ayu Gerung memang sangat membantu pelaksanaan pembelajaran khususnya mata pelajaran Pendidikan Agama Islam, dengan adanya kegiatan dari program imtaq tersebut siswa dapat memahami dan menghayati materi-materi Pendidikan Agama Islam dan dapat dikembangkan dalam kehidupan sehari-hari sebagai wujud dari hasil belajar selama di Madrasah.

\section{Catatan Akhir}

Bertitik tolak dari pembahasan dan hasil penelitian yang dilakukan oleh peneliti di lapangan, maka dapat disimpulkan sebagai berikut: (a) bahwa bentuk-bentuk kegiatan program imtaq di MI Nurul Karim NW Kebon Ayu Gerung Lombok Barat terwujud dari materi-materi yang terdiri dari materi keimanan, meteri ibadah, materi akhlak, dan materi Al-Qur'an yang 
diimplementasikan menjadi beberapa bagian dan dilaksanakan bertahap-tahap, yaitu: (a) Program Imtaq Harian, yang meliputi: (1) kegiatan sholat dhuha, (2) kegiatan membaca al-Qur'an, dan (3) berpakaian muslim yang rapi. (b) Program Imtaq Mingguan, yang meliputi: (1) kegiatan membaca surat Yasin bersama, (2) kultum (kuliyah tujuh menit), dan (3) pengumpulan amal. (c) Program Imtaq Bulanan, yang meliputi: (1) kegiatan setelah selesai semester, dan (2) kegiatan bulan Ramadhan, seperti: pelaksanaan pesantren kilat. (d) Program Imtaq Setiap Tahun, seperti: kegiatan pengajian setiap perayaan hari besar Islam seperti Maulid Nabi Muhammad SAW dan Isra' Mi'raj Nabi Muhammad SAW, pemotongan hewan Qurban dan Halal bi Halal setelah perayaan Idul Fitri dan Idul Adha setiap tahunnya.

(b) Adanya faktor-faktor yang mendukung dan menghambat dari pelaksanaan program imtaq di MI Nurul Karim NW Kebon Ayu Gerung Lombok Barat, antara lain: (1) faktor pendukung program imtaq di MI Nurul Karim NW Kebon Ayu Gerung Lombok Barat, yaitu: (a) Faktor Peserta Didik, peserta didik merupakan hal yang sangat penting karena peserta didik merupakan sasaran utama dari program imtaq di MI Nurul Karim NW Kebon Ayu Gerung Lombok Barat. (b) Faktor Pendidik, pendidik adalah salah satu faktor yang sangat penting, karena pendidik itulah yang akan bertanggung jawab dalam pembentukan anak didik. (c) Faktor tujuan dari program imtaq.

(2) Faktor penghambat program imtaq di MI Nurul Karim NW Kebon Ayu Gerung Lombok Barat, yaitu: (a) Sarana dan prasana yang belum terlalu memadai sebagai tempat pelaksanaan program imtaq khususnya kegiatan imtaq setiap minggunya. (b) Daya serap siswa terhadap materi program imtaq belum sepenuhnya terserap dengan baik karena sebagian siswa masih main-main dalam mengikuti kegiatan imtaq. (c) Masalah kedisiplinan yang menjadi penghambat terbesar dalam pelaksanaan program imtaq karena jika siswa belum menerapkan kedisiplinan maka semua program imtaq tidak akan bisa berjalan lancar sesuai dengan yang diharapkan. 
Dengan adanya program imtaq yang dilaksanakan secara rutin tersebut, telah membawa hasil dengan terjadinya perubahan yang signifikan pada anak didik di MI Nurul Karim NW Kebon Ayu Gerung. Perubahan-perubahan tersebut mencakup aspek kognitif, afektif, dan psikomotorik yang ditandai dengan tertanamnya kebiasaan-kebiasaan berbuat baik anak didik di lingkungan Madrasah maupun di luar lingkungan Madrasah.

\section{Daftar Pustaka}

Abdul Majid dan Dian Andayani, Pendidikan Agama Islam Berbasis Kompetensi, (Bandung: Rosda Karya, 2005).

Ahmad Tafsir, Ilmu Pendidikan Dalam Perspektif Islam, (Bandung, Remaja Rosda Karya, 2005).

Depag RI, Al-Qur'an dan Terjemahannya, (Jakarta : PT Sarajaya Santra, 1988).

Departemen Pendidikan Nasional, Kurikulum Tingkat Satuan

Pendidikan Pendidikan Agama Islam SMP (Jakarta: BSNP. 2006).

Departemen Pendidikan Nasional, Model Silabus dan Rencana

Pelaksanaan Pembelajaran Mata Pelajaran Pendidikan Agama Islam SMP, (Jakarta: BSNP, 2006).

Depdikbud, Kamus Bahasa Indonesia, (Jakarta, Balai Pustaka, 1990).

Dinas pendidikan kota Mataram, Pedoman Pembinaan Imtaq Bagi Sekolah/Madrasah Negeri/Swasta Di Kota Mataram (Mataram:

Dinas Pendidikan Kota Mataram Subdin Pendidikan Dasar, 2003).

Djam'an Satori dan Aan Komariah, Metodologi Penelitian Kualitatif, (Bandung, Alfabeta, 2009).

Hafni Madjid, Pengembangan Kurikulum Menuju Kurikulum Berbasis Kompetensi, (Ciputat: Kuantum Learning Ciputat Press Group, 2005).

Hary Noer,dkk., Watak Pendidikan Islam, (Jakarta: Friska Agung Insani, 2000).

Ismail Thaib, Konsep-konsep Dasar Pendidikan Agama Islam, (Mataram:

Nusa Tenggara Barat: Yayasan Lembaga Masyarakat Baru 2004). 
Lubna, Mengurai Ilmu Pendidikan Islam, (Mataram: LKIM Mataram, 2009).

M. Arifin, Ilmu Pendidikan Islam (Tinjauan Teoritis dan Praktis Berdasarkan Pendekatan Interdisipliner),(Jakarta, Bumi Aksara, 2008).

Muhaimin, Paradigma Pendidikan Islam Upaya Mengefektifkan Pendidikan Agama Islam Di Sekolah/Madrasah, (Bandung :Rosda Karya, 2010).

Muhamad Daud Ali, Pendidikan Agama Islam, (Jakarta, Raja Grafindo Persada, 2006).

Mulyasa, Pendidikan Agama Islam Berbasis Kompetensi, (Bandung: Remaja Rosda Karya, 2006).

Muzayyin Arifin, Filsafat Pendidikan Islam, Jakarta, Bumi Aksara, 2009).

Ngainun Naim, Desain Pembelajaran Pendidikan Agama Islam, (Jakarta:

Pustaka Pelajar, 2007).

Nizar, Pendidikan Agama Islam, (Bandung: Bumi Aksara, 2002).

Ramayulis, Metodologi Pendidikan Agama Islam, (Jakarta: Kalam Mulia, 2005).

Sahilun A. Nasir, Penerapan Pendidikan Agama Islam Terhadap Pemecahan Problem Remaja, (Jakarta: Kalam Mulia, 2002).

Sugiono, Metodologi Penelitian Kuantitatif, Kualitatif dan R\&D, (Bandung: Alfabeta, 2009).

Suharsimi Arikunto, Prosedur Penelitian Berdasarkan Suatu Pendekatan Praktik, (Jakarta: Rineka Cipta, 2006).

Uhbiyati, Ilmu Pendidikan Agama Islam, (Bandung: Pustaka Setia, 1996).

www.bappeda.lombokbaratkab.go.id 